\title{
Namibian Marine Fisheries Sector - Current State and Future Opportunities for Investment
}

\author{
Tangeni Haimbala
}

\author{
${ }^{*}$ University of Natural Sciences and Life Sciences \\ DOI: 10.29322/IJSRP.11.10.2021.p11802 \\ http://dx.doi.org/10.29322/IJSRP.11.10.2021.p11802
}

\begin{abstract}
Namibian Marine fisheries (MRF) have important social and economic benefits but can impact fish stocks and the environment. The diverse and dispersed nature of these fisheries makes them challenging to study; a lack of data has made it more difficult to include them in fisheries management and the varied motivations of fishers make their response to management measures hard to predict. Research into MRF is growing rapidly, so this themed article set aims to bring together MRF research to highlight the current evidence base and identify future opportunities. New survey methods were presented alongside analyses of existing data, which highlighted issues with methods, reconstruction of missing data, and factors influencing catch and effort. The manuscripts demonstrated the biological and economic impacts of MRF, and its self-subsidizing nature was recognized. Novel approaches for management, including improving compliance, were identified. Finally, the lack of funding for MRF was highlighted. Key research gaps are: governance that embeds MRF in fisheries management; integration of novel approaches and traditional surveys; risk-based approaches to identify impacts; understanding fish welfare; management that balances economic, social, and biological impacts and allows allocation between sectors; and understanding social benefits and their impacts on management and compliance.
\end{abstract}

Key words- Fishing sector, marine resources, Namibian fisheries

\section{INTRODUCTION}

$\mathrm{N}$ amibia is a stable, democratic country, which has a stimulating effect on economic development and employment through foreign investment. The Ministry of Industrialisation, Trade, and Small and Medium Enterprise Development (MITSMED) is responsible for the implementation of the Foreign Investment Act of 1990 (FIA). When it comes to bilateral ties, the country has done well in acceding key economic and trade communities, international tax treaties, and trade agreements. As a result, Namibia has several key community memberships, remarkably forming part of the Southern African Customs Union (SACU) and the Southern African Development Community (SADC).

The fisheries sector of Namibia plays an important role in the national economy, contributing significantly to employment, livelihoods, food security and to the GDP. There are opportunities to further develop the fishing sector through increasing productivity and upgrading of infrastructure. To achieve a better market access for Namibia's marine fishery resources, value chain must be well managed to deliver product of higher quality and uniqueness. This can be done through interventions at all stages of the value chain and through proper understanding of the dynamics. The paper details an analysis of the value chains of fish/seafood in Namibia, their potential and challenges when it comes to sourcing of value-added products from these value chains, relevant Namibian actors in the sectors, regulation and legislation regarding the import of fish products that are relevant for the German/European side. Value addition of major species (hake, monk and horse mackerel) at post-harvest operations and processing was also studied.

Cross cutting issues considered included matters such as corruption and transparency within the sector, access to finance and most importantly the blue economy strategy. Evaluation of existing food safety standards and certification practices at all levels of the value chain was done through interviews with officials from the Namibian Standards Institution (NSI) to review the fish processing, handling, storage practices and hygiene practice at fishing industries.

The report further highlighted where international companies have opportunities to find areas of potential investment and sourcing in the fisheries sector and to make Namibia's fish and seafood products more competitive to gain better global market access.

Namibia's coastline stretches about $1,570 \mathrm{~km}$ and is one of the most productive marine ecosystems in the world, the Benguela Current Large Marine Ecosystem (BCLME). Due to its cold and nutrient-rich upwelling, the maritime spaces off the coast of Namibia is an important ecosystem for marine biodiversity and marine food production. When it comes to fisheries capture, Namibia is ranked third in Africa, after South Africa and Morocco, and 30th worldwide. The country's commercial fishing industry is dominated by three species: hake (Merluccius capensis and Merluccius paradoxus), horse mackerel (Trachurus capensis) and monk (Lophius spp).

The fisheries sector in Namibia, including the processing, is the third largest economic sector in terms of contribution to the country's GDP and; it contributes about $15 \%$ to the country's total exports value. In 2017, it was recorded the annual marine landings of about $550000 t$ valued at an average of NAD 10 billion (about 625 million EUR) (Leandrea Louw, 2018). About 16,000 people are directly employed in the fisheries sector, while others are indirectly employed in fisheries related activities such as supply and logistics (Adam Hartman, 2019). The fisheries sector constitutes a vital component of domestic food security by 
providing a source of protein. The industry is composed of the onshore and offshore fishing and fish processing sectors, the maritime sectors and a developing aquaculture sector.

\section{METHODOLOGY}

This article has been developed based on the author's knowledge as an expert in the maritime and ocean governance field, literature review and detailed desk research. In addition, interviews with experts from the Namibian fishing industry were conducted. However, the current scandal, dubbed as 'Fishrot Scandal' in the

\section{STATE OF MARINE CAPTURES}

The commercial fishing industry is dominated by three species: Hake, Horse Mackerel and Monkfish. Species with high potential for value addition include: Hake, Monkfish and Sole, Kingklip, Orange Roughy, Horse Mackerel, Pilchard, Tuna and large pelagic, Deep Sea Red Crab and Rock Lobster. Mariculture production includes Abalone, Scallop, Pacific Oyster, Clam, Seaweed, Sea Lettuce, Silver Cob, Kelp, Yellow Tail and Oyster. Both Pacific Oysters and European Oysters are harvested in Namibia. Oysters, Mussels and Abalone are the main live bivalve molluscs with potential for export to the EU.

The current Hake total catch allowed is 154,000 t for the fishing year running 1 November 2019 to 30 September 2020, October 2020 being a month closed to fishing, which partially fits in with the fish-spawning season (https://www.undercurrentnews.com/). The Monkfish total allowable catch is currently 7200t for the fishing year running 1st May 2019 to 30 April 2020. Other species also have a maximum catching limit, but they are mostly not exported to the EU.

\section{A. Hake (Merluccius capensis and M. paradoxus)}

Estimates from the 2016 swept-area biomass survey indicated that the relative total Hake biomass was around 1.0 million tonnes, (MFMR Annual Report, 2016). There was a decrease in fishable biomass (Hake size $>35 \mathrm{~cm}$ ) of about $32 \%$ observed during the 2016 survey (MFMR Annual Report, 2016). The non-fishable biomass (Hake size $<36 \mathrm{~cm}$ ) has increased by $2 \%$. In 2016 the estimate of the recruitment potential (2014 cohort) was above the long-term average, at about 6.6 billion small fish (1.5-2 years old) (MFMR Annual Report, 2016).

\section{B. Monkfish (Lophius vomerinus)}

According to the MFMR annual report (2016), the survey of monkfish conducted during November 2016 estimated the total biomass around $33000 \mathrm{t}$, an increase of $38 \%$ relative to the total biomass from the year 2015. The survey structure showed a decrease in the medium-sized fish up to $54 \mathrm{~cm}$ and an increase in the larger fish for 2016. Recruitment was higher in 2016 compared to 2015 .

\section{Horse Mackerel (Trachurus capensis)}

In 2014, the horse mackerel stock was estimated at 1,450,000t and remains above the maximum sustainable yield (MSY) level, (MFMR annual report 2016). A total allowable catch (TAC) of $335,000 t$ was allocated for the 2016 fishing season. The midwater fleet landed about 305,109t and no catch for juvenile horse sector has negatively impacted on the research. Stakeholders were not willing to contribute to the interviews and as a result, they opted for non-disclosure of their identities. The Ministry of Fisheries and Marine Resources (MFMR) published official documentation on the sector. However, the latest data is from 2016, thus imposing a challenge for this report to present the status of the fisheries industry. Prices provided were converted from its original Namibian value at an exchange rate of 1 EUR $=$ NAD 15.9091 obtained at: https://www.xe.com/currencyconverter/ [24 Jan, 2020].

mackerel was recorded, as purse seining for fishmeal was discontinued in 2014 (MFMR annual report 2016).

\section{Sardine/Pilchard (Sardinops sagax)}

Northern Benguela sardine stock estimate remains at zero and over a period of 25 years, on five occasions the stock declined to a level below determination. Recruitment in years have been very poor and the last seasons that yielded good recruitment were the $2008 / 2009$ and 2009/2010. Purse seiners only landed $3427 \mathrm{t}$ of sardines for the 2015 fishing season against a TAC of $14000 \mathrm{t}$ ) (MFMR Annual Report, 2016).

\section{E. Deep Sea Red Crab}

According to MFMR annual report (2016), Namibian deep-sea red crab stock is one of the resources showing clear signs of recovery. The 2015 biomass survey recorded a 170\% increase in crab density compared to that of the previous year. Juvenile crabs were recorded during the 2015 survey (MFMR Annual Report, 2016), although still below the long-term average of $300 \%$ increase recorded during the 2014 survey. The 2015 Deep-Sea Red Crab (DSRC) season produced good results. The commercial fleet of four crab vessels fished intermittently for a period of 11 months to fully catch the 3446 t TAC set for the 2015 season.

\section{F. Rock Lobster}

Given that the 2015-16 TAC (250t) was reduced by $20 \%$ from that of the preceding season, the Rock Lobster industry fared well in landing $94 \%$ of the 2015-16 TAC.

\section{G. Large pelagic (Tuna, swordfish \& large pelagic sharks)}

The large pelagic fishery consists of a Bait boat Fleet targeting tuna (mainly albacore, big eye and yellowfin tuna), the Pelagic Longline Fleet targeting swordfish, and large pelagic sharks (mainly blue shark and shortfin mako). The bait boat landings reported for 2016 were $804.7 \mathrm{t}$ Bigeye Tuna catches increased to $105.9 \mathrm{t}$ and yellowtail tuna landed at $0.4 \mathrm{t}$. Both swordfish and blue shark increased by $13 \%$ to $258.7 \mathrm{t}$ and $2,451.1 \mathrm{t}$ respectively and shortfin mako increased by $17 \%$ to $798.8 \mathrm{t}$. Other catches landed by the fishery are albacore $(0.2 \mathrm{t})$, bigeye tuna $(81.7 \mathrm{t})$, blue marlin $(8.1 \mathrm{t})$, bluefin tuna $(0.2 \mathrm{t})$, longfin mako shark $(31.8 \mathrm{t})$, thresher sharks (13.3t), yellowtail tuna (13.3t) and yellowfin tuna (35.2t). 


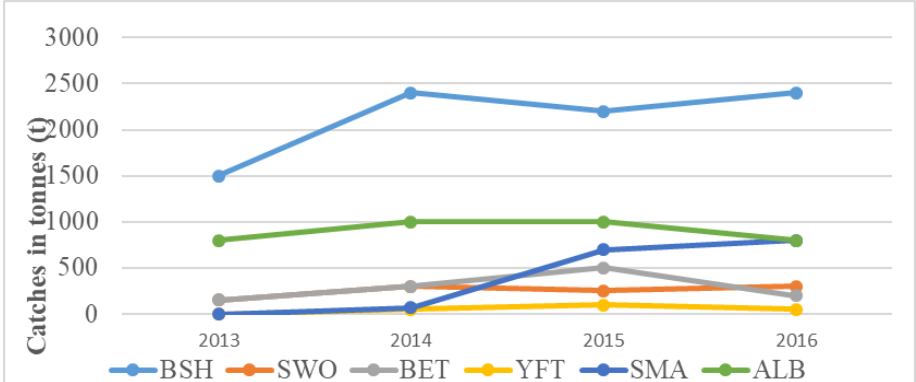

Figure 1:Combined catches of the targeted species between 2013 and 2016, no later data available (Source MFMR, Annual Report 2016)

(Source: MFMR, Annual Report 2016).

$\mathrm{BSH}=$ Blue Shark, $\mathrm{SWO}=$ Swordfish, BET $=$ Bigeye Tuna, YFT= Yellow fish Tuna, $\mathrm{SMA}=$ Shortfin Mako, $\mathrm{ALB}=$ Albacore

\section{H. Cape Fur Seals (Arctocephalus pusillus spp. Pusillus}

The latest (MFMR Ministerial presentation, 2017) assessment estimated the seal population at around 1.08 million and is expected to remain above this level. A new rolling TAC set 60,000 pups and 8,000 bulls for 2016-2018. The main products derived from seals are skin, seal oil and organs. In terms of value addition, pelts are processed into wet salted form, seal organs are dried, and meat is cooked with salt to make seal meal (for animal feeds).

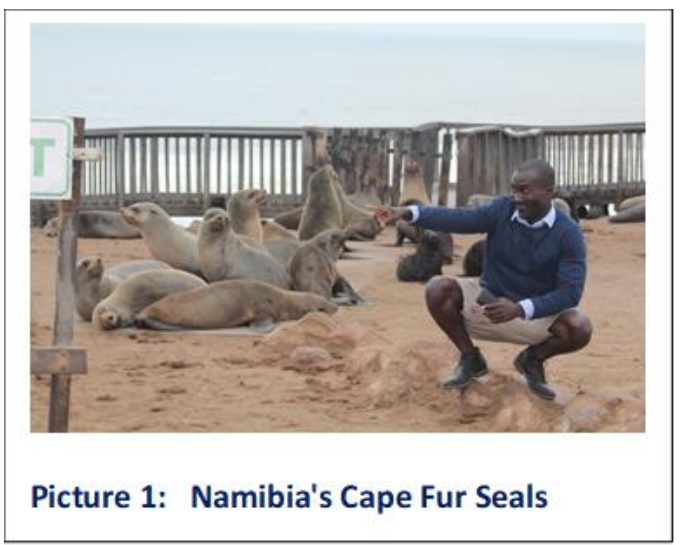

Table 1:Total Allowable Catch (TAC) and harvest of seals 2012-2016 (Source: MFMR presentation, Economic Division Directorate of Policy, Planning and Economics 2017)

\begin{tabular}{llllllllll}
$\begin{array}{l}\text { Harves } \\
\text { ting } \\
\text { Season }\end{array}$ & TAC & \multicolumn{3}{c}{$\begin{array}{l}\text { Quota } \\
\text { Allocated }\end{array}$} & Harvests & \multicolumn{3}{c}{$\begin{array}{l}\text { Under } \\
\text { harvesti } \\
\text { ng }\end{array}$} \\
& Pup & Bull & Pup & Bull & Pup & Bull & $\begin{array}{l}\text { Pu } \\
\text { Bul }\end{array}$ \\
& s & s & s & s & s & s & ps & Is \\
$\mathbf{2 0 1 2}$ & 80,0 & 6,0 & 80,0 & 6,0 & 53,3 & 4,5 & 43 & 25 \\
& 00 & 00 & 00 & 00 & 39 & 11 & & \\
2013 & 80,0 & 6,0 & 80,0 & 6,0 & 48,6 & 3,6 & 39 & 40 \\
& 00 & 00 & 00 & 00 & 88 & 03 & & \\
2014 & 80,0 & 6,0 & 54,8 & 6,0 & 35,5 & 5,7 & 45 & 8 \\
& 00 & 00 & 24 & 00 & 30 & 01 & & \\
2015 & 80,0 & 6,0 & 80,0 & 6,0 & 34,9 & 6,1 & 56 & 3 \\
& 00 & 00 & 00 & 00 & 74 & 59 & & \\
2016 & 60,0 & 8,0 & 60,0 & 8,0 & 14,6 & 6,1 & 76 & 23 \\
& 00 & 00 & 00 & 00 & 03 & 75 & &
\end{tabular}

This publication is licensed under Creative Commons Attribution CC BY
Hong Kong and China are the main international markets for seal products. The profit realised for that year was about $\mathrm{N} \$ 10,207$, 1956. Turkey, China and South Korea are also the main market for dried genitals and wet salted skin.

Table 2:Export of tanned skins

(Source: MFMR presentation, Economic Division Directorate of Policy, Planning and Economics 2017)

\begin{tabular}{|c|c|c|c|c|c|c|}
\hline \multirow{2}{*}{\multicolumn{2}{|c|}{ Destination }} & \multicolumn{5}{|c|}{ Exporting Year } \\
\hline & & 2012 & 2013 & 2014 & 2015 & 2016 \\
\hline \multirow{4}{*}{$\begin{array}{l}\text { Asia \& } \\
\text { Eurasia }\end{array}$} & China & 4,120 & 19 & 0 & 1,947 & 36 \\
\hline & $\begin{array}{l}\text { Hong } \\
\text { Kong }\end{array}$ & 0 & 300 & 0 & 4,279 & 0 \\
\hline & Japan & 1,888 & 0 & 0 & 58 & 1,500 \\
\hline & Singapore & 2 & 0 & 0 & 0 & 630 \\
\hline \multirow{9}{*}{ Europe } & Russia & 11 & 1 & 0 & 0 & 0 \\
\hline & Turkey & 16,878 & 0 & 0 & 0 & 0 \\
\hline & Ukraine & 27 & 137 & 0 & 0 & 0 \\
\hline & Estonia & 27 & 0 & 0 & 0 & 0 \\
\hline & Germany & 0 & 0 & 0 & 10 & 2 \\
\hline & $\begin{array}{l}\text { United } \\
\text { Kingdom }\end{array}$ & 0 & 0 & 0 & 2 & 0 \\
\hline & Austria & 0 & 0 & 0 & 2 & 0 \\
\hline & Italy & 0 & 0 & 0 & 2 & 0 \\
\hline & $\begin{array}{l}\text { Czech } \\
\text { Republic }\end{array}$ & 0 & 0 & 0 & 2 & 0 \\
\hline $\begin{array}{l}\text { North } \\
\text { America }\end{array}$ & Canada & 900 & 3 & 0 & 0 & 0 \\
\hline $\begin{array}{l}\text { South } \\
\text { America }\end{array}$ & Brazil & 100 & 0 & 0 & 0 & 1,500 \\
\hline \multirow[t]{2}{*}{ Africa } & Angola & 0 & 0 & 0 & 10 & 0 \\
\hline & RSA & 4,830 & 1,000 & 0 & 503 & 0 \\
\hline Total & & 28,783 & 1,460 & 0 & 6,873 & 3,668 \\
\hline
\end{tabular}

The above mentioned are skins processed according to clients' specifications. They can be used for clothing, shoes, gloves, fur hats, straps, handbags etc. The tanning of the seal skins prevents it from deteriorating.

\section{RECREATIONAL SECTOR}

The Namibian marine environment supports a highly esteemed recreational fishery. Both local and international anglers, targeting a wide range of line fish species, exploit recreational sector. Fishing for recreational purposes is allowed all-year round, with the season commencing each October.

All recreational fishery is for own consumption and local sales only.

\section{A. Snoek (Thyrsitess atun)}

Snoek is a migratory and seasonal species, which is not managed by an annual TAC. Therefore, a person may not, for recreational 
purposes, in one day harvest more than 30 Snoek, Marine Resources Act, (Act No 27 of 2000).

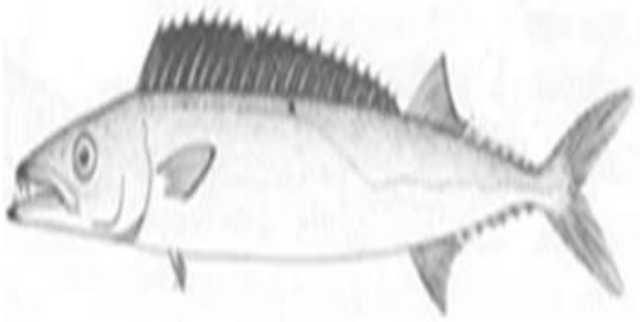

\section{Source: MFMR Annual Report 2016}

\section{B. Silver cob (Argyrosomus inodorus)}

The Namibian silver cob is only abundant off central and northern Namibia and it is the most popular species of the angling fishery. Both rock-and-surf anglers and ski-boat anglers in water shallower than 20m deep exploit silver cob. During the 2015/2016 fishing season 119t (49,675 individuals) of cob where caught (MFMR, 2016).

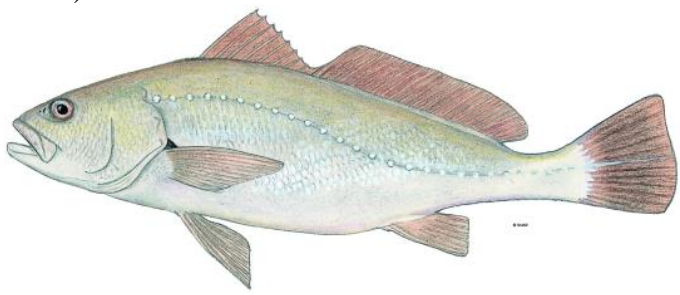

Source: MFMR Annual Report 2016

\section{West Coast Steenbras (Lithognathus aureti)}

Two distinct West coast Steenbras populations occur in the Namibian waters, a southern population found in the closed area; Namibian Islands' Marine Protected Area (NIMPA) around Moe Bay and it is thus unavailable for recreational activities. The second population occurs in the central and northern regions of the Namibian coast and shore anglers exploit it. For the 2015/2016 fishing season, anglers caught about 14t (5 583 individuals) of Steenbras (MFMR, 2016).

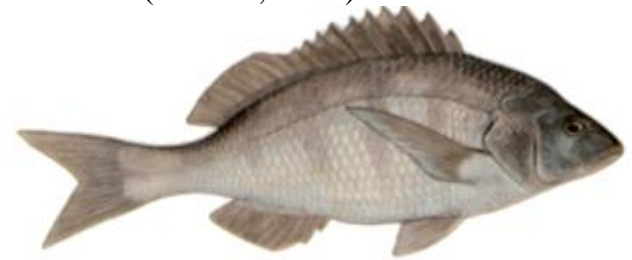

Source: MFMR Annual Report 2016

\section{OVERVIEW OF THE FISHERIES VALUE CHAIN}

Namibia is a major fish exporting country and fish continues to be Namibia's number one export revenue earner in terms of food items. Currently over $70 \%$ of the hake exported from Namibia land in European countries, most prominently in the Southern European countries of Spain, Portugal, Italy and France where the hake (Merluccius capensis) is the preferred white fish species and consumers are prepared to pay a high price for the fish. The bulk of Namibian hake is delivered into Europe. In 2016, Spain absorbed $34 \%$ or NAD 2.995 million1 of total domestic fish exports (MFMR Annual report, 2016) the largest share of Namibia's fish exports in that year. In countries further North such as Germany, Austria, Holland and Sweden, hake is not commonly known. White fish species such as Codfish and Alaskan Pollock dominate their markets. Close to $85 \%$ of the Namibian monk ends up in the European Union.

The representative of the Namibian Hake Association (NHA), $\mathrm{Mr}$ Ron Wolters, is projecting that the hake biomass is undergoing rebuilding which will take about five years to reach its maximum sustainable yield (MSY). This means that the Total Allowable Catch (TAC) will rise slowly which in turn means that no big jumps in the quota is expected and if industry wants a bigger return from its catch, the value addition is the way to go. NHA further estimates that the monk is fished at MSY that implies that there will be no growth in the biomass. As a result, the TAC will remain at its current level.

According to Wolters, as far as the hake is concerned, industry is very far into value adding as possible with natural products. The next phase would be battering or crumbing the fillets/cuts and ready meals. While the SADC EU Economic Partnership Agreement (EPA) allows duty free imports into the European Union (EU) on natural fish products, it excludes products with batter or crumbs. In general, Namibian sales into Europe do not cover the full demand but if nature does not provide more, there is little that can be done.

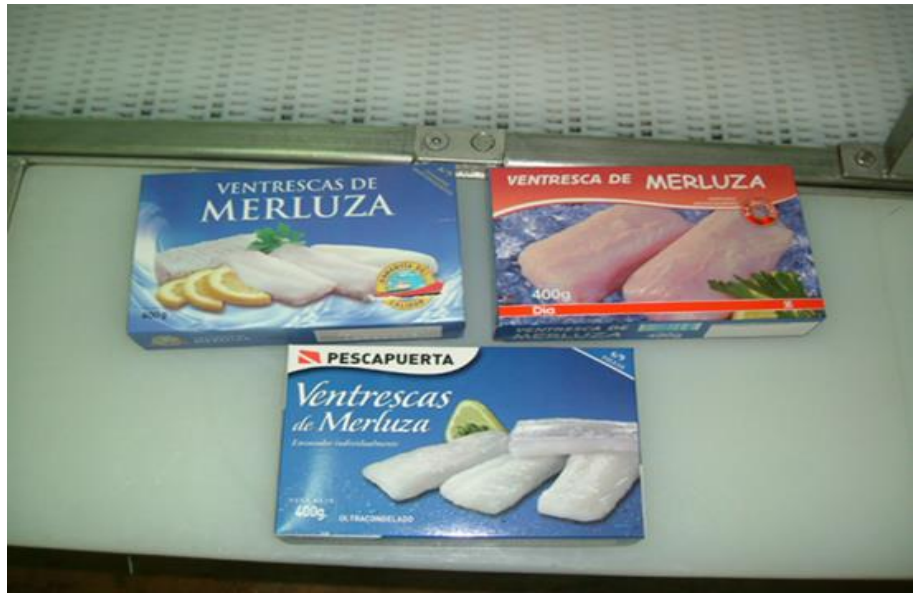

Photo 1:Tunacor's hake belly portions under a range of brands, sold to the Spanish market

Fillets, raw, merely coated with batter or breadcrumbs, whether or not pre-fried in oil, frozen have Customs duties of 7.5\% [Stated in Official Journal of the European Union L 250/3 dated 16.09.2016. EPA agreement between the European Union and its Member States, of the one part, and the SADC EPA States, of the other part]. However, if the export of value-added crumbed products is allowed, this could open opportunities for companies to increase revenues, which will have a positive impact on job creation. 


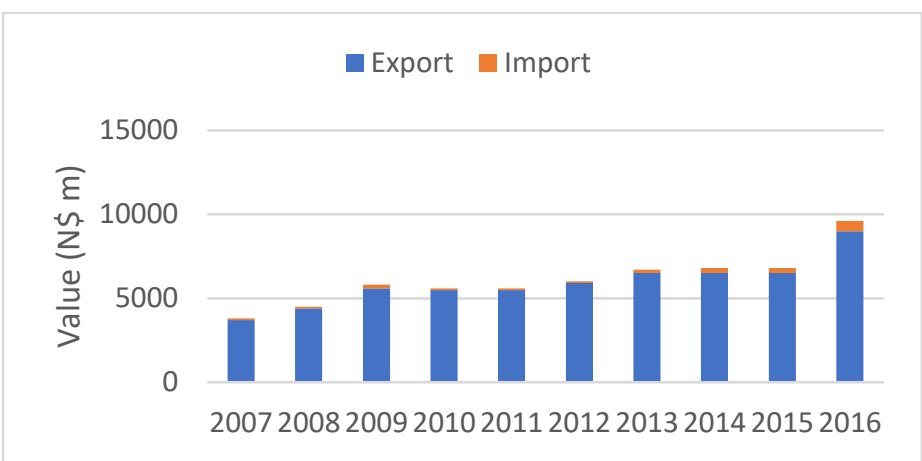

Figure 2:Upward trend of fish exports \& imports over the ten-year period from 2007-2016 (Source: NSA 2016).

\section{A. Potential for value addition}

Namibia's marine resources with high potential for value addition include, listed based on their potential: Hake (the single most relevant catch in terms of value and the single most important catch in terms of tonnage landed, second in value),

Monkfish, Horse Mackerel, Pilchard, Sole, Kingklip, Orange Roughy, Tuna and large pelagic, deep sea Red Crab and Rock

Lobster. Some of the value additions are filleting, canning, packaging, smoking, fish oil and fishmeal production as summarised below (Table 3). 
Table 3:Value-added products per sub-sector in 2015/16 (Source: MFMR Annual Report 2016)

\begin{tabular}{|c|c|c|}
\hline Sub-sector & Products & $\begin{array}{ll}\text { 2015/16 } & \text { Prices } \\
\text { (N\$)/NAD } & \\
\end{array}$ \\
\hline \multirow[t]{3}{*}{ Seals } & Seal Oil & N\$300/litre \\
\hline & Seal Skins & $\mathrm{N} \$ 116 /$ skin \\
\hline & Seal Organs & $\mathrm{N} \$ 350 / \mathrm{kg}$ \\
\hline \multirow[t]{5}{*}{ Crab } & Frozen whole round & $\mathrm{N} \$ 42.50 / \mathrm{kg}$ \\
\hline & Crab meat & $\mathrm{N} \$ 178 / \mathrm{kg}$ \\
\hline & Crab flakes & $\mathrm{N} \$ 58.91 / \mathrm{kg}$ \\
\hline & Crab sections & $\mathrm{N} \$ 87.39 / \mathrm{kg}$ \\
\hline & Crab legs & $\mathrm{N} \$ 95 / \mathrm{kg}$ \\
\hline \multirow[t]{4}{*}{ Pilchard } & Canned Pilchard & $\mathrm{N} \$ 108 /$ tray \\
\hline & Fish meal & N\$ 11.74/kg \\
\hline & Fish oil & N\$ 13.19/liter \\
\hline & Cutlets and bait & $\mathrm{N} \$ 20 / \mathrm{kg}$ \\
\hline \multirow[t]{4}{*}{ Monk } & $\begin{array}{lll}\begin{array}{l}\text { Monk } \\
\text { Frozen }\end{array} & \text { Tails } & \text { Sea } \\
\end{array}$ & $\mathrm{N} \$ 112.14 / \mathrm{kg}$ \\
\hline & $\begin{array}{lll}\text { Monk } & \text { Fillets Land } \\
\text { Frozen } & & \\
\end{array}$ & $\mathrm{N} \$ 123.83 / \mathrm{kg}$ \\
\hline & $\begin{array}{ll}\text { Monk Tails shrink } \\
\text { wrapped }\end{array}$ & $\mathrm{N} \$ 123.00 / \mathrm{kg}$ \\
\hline & Monk tails land frozen & $\mathrm{N} \$ 89.80 / \mathrm{kg}$ \\
\hline \multirow[t]{2}{*}{ Rock Lobster } & $\begin{array}{l}\text { Whole cooked and } \\
\text { Raw lobster }\end{array}$ & $\mathrm{N} \$ 310.00 / \mathrm{kg}$ \\
\hline & Live Lobster & $\mathrm{N} \$ 430.78 / \mathrm{kg}$ \\
\hline \multirow[t]{3}{*}{ Hake } & Headed \& Gutted & $\mathrm{N} \$ 24.86 / \mathrm{Kg}$ \\
\hline & Frozen Hake fillets & $\mathrm{N} \$ 50.08 / \mathrm{Kg}$ \\
\hline & $\begin{array}{lr}\text { Primerer } & \text { Cuts, } \\
\text { Medallions, } & \text { Blocks, } \\
\text { Steaks, } & \text { Sausages, } \\
\text { Loins, Prime Quality } \\
(\mathrm{PQ}), \quad \text { Individually } \\
(\mathrm{IQF}) & \\
\end{array}$ & $\mathrm{N} \$ 35.52 / \mathrm{kg}$ \\
\hline \multirow[t]{2}{*}{$\begin{array}{l}\text { Horse } \\
\text { Mackerel }\end{array}$} & $\begin{array}{l}\text { Overland } \\
\text { whole }\end{array}$ & $\mathrm{N} \$ 9.32 / \mathrm{kg}$ \\
\hline & $\begin{array}{l}\text { Transhipment Frozen } \\
\text { whole }\end{array}$ & $\mathrm{N} \$ 11.35 / \mathrm{kg}$ \\
\hline \multirow[t]{2}{*}{ Tuna } & $\begin{array}{l}\text { Polling whole round } \\
\text { Tuna }\end{array}$ & $\mathrm{N} \$ 21.50 / \mathrm{kg}$ \\
\hline & $\begin{array}{l}\text { Longline whole round } \\
\text { (For Sashimi) }\end{array}$ & $\mathrm{N} \$ 31.60 / \mathrm{kg}$ \\
\hline Swordfish & Whole round (WR) & $\mathrm{N} \$ 52.10 / \mathrm{kg}$ \\
\hline
\end{tabular}

\section{B. Flat Markets}

Namibia continues to have an advantage in markets for its marine products due to the productive upwelling of the Benguela Current System. The efforts in securing markets, increasing market shares and diverting from flat markets (Table 4) has been evident as right holders continued presenting and marketing Namibian fish and fish products at both local and international levels.

\section{Landed Value per Species}

The landed value is determined by comparing values from the fishing industry and customs and excise. This value is highly influenced by the quality of the fish catches and the size. Namibia's fishery products are not and cannot be sold immediately as the fish is landed. The levies per tonne of fish landed have to be determined first. This has forced companies to keep their prices low in order to attract buyers. The latter makes Namibian companies a price taker.

Table 4:Markets and market shares per sub-sector (Source: MFMR Annual Report 2016)

\begin{tabular}{|c|c|c|c|}
\hline \multirow{2}{*}{$\begin{array}{l}\text { Sub- } \\
\text { sector }\end{array}$} & \multirow[t]{2}{*}{ Markets } & \multicolumn{2}{|c|}{ Market Share Values (\%) } \\
\hline & & $2015 / 16$ & $2016 / 17$ \\
\hline \multirow[t]{6}{*}{ Hake } & Spain & 26 & 30 \\
\hline & South Africa & 8 & 15 \\
\hline & $\begin{array}{ll}\text { Rest } \\
\text { Europe }\end{array}$ & 38 & 33 \\
\hline & Australia & 10 & 12 \\
\hline & Namibia & 17 & 10 \\
\hline & Others & 1 & 0 \\
\hline \multirow[t]{4}{*}{ Monk } & Spain & 70 & 71 \\
\hline & Italy & 20 & 29 \\
\hline & England & 5 & 0 \\
\hline & France & 5 & 0 \\
\hline \multirow{5}{*}{$\begin{array}{l}\text { Horse } \\
\text { Mackerel }\end{array}$} & Zambia & $33 \%$ & $18 \%$ \\
\hline & Mozambique & $28 \%$ & $17 \%$ \\
\hline & DRC & $17 \%$ & $39 \%$ \\
\hline & South Africa & $12 \%$ & $16 \%$ \\
\hline & Others & $10 \%$ & $10 \%$ \\
\hline \multirow[t]{5}{*}{ Crab } & Spain & $41 \%$ & $65 \%$ \\
\hline & $\begin{array}{l}\text { Mainland } \\
\text { China }\end{array}$ & $21 \%$ & $9 \%$ \\
\hline & South Korea & $18 \%$ & $13 \%$ \\
\hline & Japan & $13 \%$ & $4 \%$ \\
\hline & South Africa & $7 \%$ & $9 \%$ \\
\hline \multirow[t]{5}{*}{ Pilchard } & South Africa & $34 \%$ & $67 \%$ \\
\hline & Asia & $25 \%$ & $0 \%$ \\
\hline & Namibia & $41 \%$ & $16 \%$ \\
\hline & Mauritius & $0 \%$ & $16 \%$ \\
\hline & Botswana & $0 \%$ & $1 \%$ \\
\hline \multirow{3}{*}{$\begin{array}{l}\text { Rock } \\
\text { Lobster }\end{array}$} & Japan & $86 \%$ & $100 \%$ \\
\hline & China & $8 \%$ & $0 \%$ \\
\hline & Namibia & $6 \%$ & $0 \%$ \\
\hline
\end{tabular}




\begin{tabular}{|l|l|l|l|}
\hline \multirow{2}{*}{$\begin{array}{l}\text { Sub- } \\
\text { sector }\end{array}$} & Markets & \multicolumn{2}{|l|}{ Market Share Values (\%) } \\
\cline { 3 - 4 } & $2015 / 16$ & $2016 / 17$ \\
\hline Seals & $\begin{array}{l}\text { Mainland } \\
\text { China }\end{array}$ & $47 \%$ & $96 \%$ \\
\cline { 2 - 4 } & $\begin{array}{l}\text { Hong } \\
\text { Kong }\end{array}$ & $19 \%$ & $0 \%$ \\
\cline { 2 - 4 } & Turkey & $33.3 \%$ & $0 \%$ \\
\cline { 2 - 4 } & Namibia & $0 \%$ & $4 \%$ \\
\hline
\end{tabular}

\section{Landed Value per Species}

The landed value is determined by comparing values from the fishing industry and customs and excise. This value is highly influenced by the quality of the fish catches and the size. Namibia's fishery products are not and cannot be sold immediately as the fish is landed. The levies per tonne of fish landed have to be determined first. This has forced companies to keep their prices low in order to attract buyers. The latter makes Namibian companies a price taker.

Table 5: Landed values in 2016 (Source: MFMR Annual Report 2016)

\begin{tabular}{|l|l|l|}
\hline $\begin{array}{l}\text { Targeted } \\
\text { fishery } \\
\text { species }\end{array}$ & $\begin{array}{l}\text { Form } \\
\text { landed }\end{array}$ & $\begin{array}{l}\text { Landed } \\
\text { (NAD/kg) }\end{array}$ \\
\hline Hake & $\begin{array}{l}\text { Headed \& } \\
\text { Gutted }\end{array}$ & 25.00 \\
\hline $\begin{array}{l}\text { Horse } \\
\text { Mackerel }\end{array}$ & Whole & 9.50 \\
\hline Crab & Whole & 52.40 \\
\hline $\begin{array}{l}\text { Rock } \\
\text { Lobster }\end{array}$ & Whole & 193.60 \\
\hline Pilchard & Whole & 4.40 \\
\hline $\begin{array}{l}\text { Monk } \\
\text { Headed \& }\end{array}$ & 51.20 \\
\hline Albacore & Whole & 22.00 \\
\hline Swordfish & Whole & 49.00 \\
\hline $\begin{array}{l}\text { Snoek } \\
\text { Frozen }\end{array}$ & Whole & 21.80 \\
\hline $\begin{array}{l}\text { Big eye } \\
\text { Tuna }\end{array}$ & Whole & 22.00 \\
\hline All Sharks & Whole & 22.00 \\
\hline Oil Fish & Whole & 24.00 \\
\hline Sole & Gutted & 23.00 \\
\hline Kingklip & $\begin{array}{l}\text { Headed \& } \\
\text { Gutted }\end{array}$ & 42.38 \\
\hline
\end{tabular}

VI. QUALITY AND STANDARDS

It is outlined in the EU law (Article 11 of Regulation (EC) No 854/2004 of the European Parliament and of the Council of 29 April 2004) that the products of animal origin from third countries must comply with requirements that prevent the introduction of animal diseases into the EU. The EU recognises the Namibia Standard Institution (NSI)'s Fishery Inspectorate division and Veterinary Office, the Directorate-General for Health and Food Safety (DG-SANCO) as the competent authorities to exercise official controls and product certification on fishery products destined for the EU market (NSI Annual Report 2019).

The adherence to the provisions and control systems in place at the (NSI) is one of the key performance indicators (KPI) of the country's national quality infrastructure. The Namibian Standards Council (NSC) governs the NSI and it operates in terms of the Standards Act, 2005 (Act No. 18 of 2005). The expected results of the NSI programme are an established and functional national standards body in Namibia, capable of the following:

Developing, adopting and applying standards.

Providing accurate measurement traceability to the international standards (SI) through the metrology division.

Providing reliable testing especially for food such as fish and fishery products including shellfish, beef and agri-products and rendering food safety technical support to the aquaculture, fishing and other industries through regular tests conducted at the NSI Bio toxins and Microbiology laboratories at Walvis Bay and through NSI Inspection and Certification.

\section{FISH PROCESSING}

Currently, approximately 30 marine resource-processing plants operate off Namibia's shores. Prior to Independence, foreign companies dominated the fisheries sector, but the postindependence fisheries development policy has resulted in majority Namibian ownership (private) across the sector. However, the MFMR continuously promote an increase in fish processing onshore by promoting investment and letting in new companies that create additional employment. The following Priority Actions have been defined:

- Priority Action F1: Horse mackerel processing support programme

- Priority Action F2: Fish processing support programme

- Priority Action F3: Fish product certification scheme Priority Action F4: Crayfish export marketing diversification

There is no timeframe for the above and with the current political situation, it's made more difficult.

\section{Table 6:Fishing companies in Namibia}

$\begin{array}{ll}\text { Name of company } & \text { Town } \\ \text { Novanam Limited } & \text { Lüderitz } \\ \text { Etosha Fisheries Holding } & \text { Walvis Bay } \\ \text { Merlus Fishing } & \text { Walvis Bay } \\ \text { Tunacor Fisheries Limited } & \text { Walvis Bay } \\ \text { Embwinda Fishing } & \text { Walvis Bay } \\ \text { Pereira Seafood Company } & \text { Walvis Bay } \\ \text { Seawork Fish Processors } & \text { Walvis Bay } \\ \text { Benguela Fishing company } & \text { Walvis Bay } \\ \text { Gendev Fishing Group } & \text { Walvis Bay } \\ \text { Namsov Fishing Enterprises } & \text { Walvis Bay } \\ \text { Hangana Seafood } & \text { Walvis Bay } \\ \text { Omualu Fishing Processor } & \text { Walvis Bay }\end{array}$




\section{Seaflower Lobster \& Wetfish Lüderitz Corporation}

The companies are not mentioned in a particular order, but they are the most relevant and commercially well established. Unfortunately, not all ownerships are known to the authors.

\section{GOVERNANCE}

Namibia incorporates a stringent regulatory system empowered by the provision in the Marine Resource Act (Act 27 of 2000) which outlines the procedures for applying for fishing rights and allocation of fishing quotas. It sets out the procedures, criteria for licensing fishing vessels and controlling fishing activities. The act empowers the MFMR to take management measures including; setting TACs, specification of fishing gears, management measures to protect the juvenile fish, minimum fish sizes to be landed, restriction of bycatch, regulating fishing seasons and transboundary activities.

The main purpose of fishing rights is to limit entry into the fishing sector in order to protect the fisheries and marine resources and ensure responsible utilisation, conservation, protection and promotion of marine resources in a sustainable manner. According to the Marine Resource Act (Act 27 of 2000), the process of granting right to harvest consists of six stages namely: (1) invitation to the public (2) preparation and delivering of applications, (3) appointment of the evaluation committee, (4) evaluation process, (5) cabinet endorsement, (6) announcement and notifications.

While priority for granting rights and allocation of quotas is given to Namibians and Namibian businesses, there is also a scope for foreign investment as wholly owned where a foreign investment company can commit to contribute to economic development in Namibia such provision of studies bursaries to marginalised communities

To gain fishing rights, fishermen pay quota fees, a form of resource rent that must be paid to the government irrespective of whether the holder catches fish or not. The fee or levy is set in such a way that those utilising Namibian-owned vessels pay lower fees than those hiring foreign-owned vessels. In addition, hake right holders using Namibian-owned vessels and carrying over 90\% Namibian crew pay a lower fee compared to vessels employing fewer Namibians. Any fish landed onshore is subject to lower quota fees. Fishing companies are obliged to contribute to the Marine Resources Fund Levy, which is collected by relevant authority to fund research, training and development in the fisheries sector. For the benefit of the Marine Resources Fund of the landed value, holders pay $2 \%$ in respect of any of the species of marine resources allocated and $15 \%$ in respect of any by-catch of any species (Government Gazette no 6342, 2017). Additionally, a person who lands any marine resources or portions of marine resources for recreational purposes, except for subsistence fishing, pays N\$ 1500 levy per month in respect of every fishing permit issued for the benefit of the Marine Resource Fund.

The allocation of fishing quotas is based on equitable distribution, onshore investment and employment. The duration of the fishing rights can range from 5-20 years, and furthermore depends on several criteria. Longer rights are issued to companies who are Namibian, i.e., majority owned by Namibian citizens, employ Namibians, have a proven record of accomplishment in the industry and have demonstrated a long-term commitment by investing in the fishing sector such as marine research, better employment conditions and a substantial contribution to the Namibian Maritime Fisheries Institute (NAMFI) for educating the seagoing personnel.

\section{A. Institutional Stakeholders and Representatives}

The main stakeholders in the fisheries sector are government decision-makers (including the Ministry of Fisheries and Marine Resources (MFMR), the Ministry of Industrialisation, Trade \& SME Development (MITSMED)). State agencies such as the Namibian Standards Institution (NSI) and National Chamber of Commerce \& Industry (NCCI)), private sector (representing the key marine sectors such as fishing associations, business, fishing/ processing companies and industries) and civil society (representing non-governmental and public interests).

The Namibian fishing associations are: the Namibian Hake Association, the Namibian Horse Mackerel Association, the Monk \& Sole Association, Small Pelagic Association, Large Pelagic Association, the Namibian Rock Lobster Fishing Association, the Hand line Fishing Association, The Crab Fishing Association, the Deep-Water Trawling Association and Namibian Mariculture Association.

The Ministry of Fisheries and Marine Resources (MFMR) oversees sustainable management of the marine resources and the promotion of aquaculture sector. Some important legal documents that govern the sector include:

Policy statement on granting of rights of exploitation to utilise marine resources and on the allocation of fishing quotas (1993);

- The Marine Resource Act (Act 27 of 2000) \& Government Gazette No. 6601/2018;

- Inland Fisheries Policy (1995);

- Aquaculture Act (Act 1 of 2002);

- Inland Fisheries Resources Act (Act 1 of 2003), which governs inland fisheries.

- Namibia's Marine Resources Policy (2004) \& Vessel Monitoring Regulations (2005)

In addition, the MFMR continues to participate actively in numerous Regional Fisheries Management Organisations (RFMOs), including the South East Atlantic Fisheries Organization (SEAFO), International Commission for the Conservation of Atlantic Tunas (ICCAT) and Benguela Current Commission (BCC).

The Namibian Governments has established and mandated several state-owned enterprises which seeks to support consumer education, resource promotional, value addition and $M \& E$ and reporting functions in the fisheries and marine resources sector on the governments behalf. Table 6 summarises these SOEs. 
Table 7:Public enterprises or State-owned enterprises under the MFMR and their mandates

\begin{tabular}{|l|l|}
\hline $\begin{array}{l}\text { State-Owned } \\
\text { Enterprises (SOE's) }\end{array}$ & Mandates \\
\hline $\begin{array}{l}\text { The Fisheries } \\
\text { Observer Agency }\end{array}$ & $\begin{array}{l}\text { Responsible for independently } \\
\text { (Foserving the activities of } \\
\text { harvesting, handling and } \\
\text { processing, collecting data and } \\
\text { biological samples. }\end{array}$ \\
\hline $\begin{array}{l}\text { Namibian Maritime } \\
\text { and Fisheries Institute } \\
\text { (NAMFI) }\end{array}$ & $\begin{array}{l}\text { A key government institution on } \\
\text { human resources capacity } \\
\text { development that provides } \\
\text { international quality (certifiable) } \\
\text { training. }\end{array}$ \\
\hline $\begin{array}{l}\text { National Fishing } \\
\text { Corporation } \\
\text { (FISHCOR) }\end{array}$ & $\begin{array}{l}\text { To undertake governmental } \\
\text { objectives in fishing, value } \\
\text { addition, research, financing } \\
\text { governmental objectives in } \\
\text { fisheries, facilitating new } \\
\text { businesses and modernization in } \\
\text { partnership with the private } \\
\text { sector. }\end{array}$ \\
\hline $\begin{array}{l}\text { Namibia } \\
\text { Consumption } \\
\text { Promotion } \\
\text { (NFCPT) }\end{array}$ & Fish \\
and & $\begin{array}{l}\text { To promote fish consumption in } \\
\text { Namibia and ensure that per } \\
\text { capita fish consumption in } \\
\text { Namibia increases from 8kg per } \\
\text { person per year (in 2016), to the } \\
\text { world average of 20.4kg per } \\
\text { person per year (FAO). }\end{array}$ \\
\hline $\begin{array}{l}\text { Hanganeni Artisanal } \\
\text { Fishers Association } \\
\text { (HAFA) }\end{array}$ & $\begin{array}{l}\text { To enhance the participation of } \\
\text { small scale and artisanal fishers } \\
\text { in the fishing industry. }\end{array}$ \\
\hline
\end{tabular}

\section{B. Namibian Fisheries Strategies}

As outlined in the NDP5 under sustainable fisheries management, Namibia is committed to be a key fisheries and processing hub in the South West Atlantic Ocean through the increase of the volume of fish handled, canned or processed in Walvis Bay. The NDP5 also outlined the commitment to increase value addition on fish and seafood.

Table 8: Strategies of the Namibian fisheries sector for 2017-2022 (Source: NDP5 2017)

\begin{tabular}{|l|l|}
\hline Fisheries Strategies & \\
\hline Enhance market access & $\begin{array}{l}\text { By ensuring compliance to } \\
\text { stringent sanitary and } \\
\text { phytosanitary standards to } \\
\text { import destinations. }\end{array}$ \\
\hline $\begin{array}{l}\text { Incentivize fish imports for } \\
\text { sustainable value addition }\end{array}$ & $\begin{array}{l}\text { By promoting importation of } \\
\text { fish in order to achieve } \\
\text { economies of scale that make } \\
\text { value addition profitable. } \\
\text { Value addition is taking place } \\
\text { on a small scale in Namibia, }\end{array}$ \\
\hline
\end{tabular}

This publication is licensed under Creative Commons Attribution CC BY.

http://dx.doi.org/10.29322/IJSRP.11.10.2021.p11802

\begin{tabular}{|l|l|}
\hline & $\begin{array}{l}\text { currently on horse mackerel } \\
\text { for both local consumption } \\
\text { and for international sale. } \\
\text { However, value addition of } \\
\text { imported fish takes place in } \\
\text { South Africa, Spain and } \\
\text { Morocco. Fisheries caught in } \\
\text { Namibia, processed in those } \\
\text { countries and sold back to } \\
\text { Namibia for consumption. }\end{array}$ \\
\hline $\begin{array}{l}\text { Increase value addition and } \\
\text { investments in onshore } \\
\text { process }\end{array}$ & $\begin{array}{l}\text { By introducing the 70/30 ratio } \\
\text { to horse mackerel, include } \\
\text { more consumer-ready } \\
\text { products, and ensure that 50\% } \\
\text { of the total allowable catch is } \\
\text { value added before export. }\end{array}$ \\
\hline $\begin{array}{l}\text { Develop retail ready products } \\
\text { in the hake and white fisheries } \\
\text { such as monk in the Namibian } \\
\text { local market }\end{array}$ & $\begin{array}{l}\text { To improve value addition in } \\
\text { hake and white fisheries } \\
\text { species and ensure that the } \\
\text { allocation of fish quotas is } \\
\text { conditional on ability to add } \\
\text { value. }\end{array}$ \\
\hline $\begin{array}{l}\text { Promote investment } \\
\text { mariculture }\end{array}$ & $\begin{array}{l}\text { To promote mariculture as a } \\
\text { viable economic option by } \\
\text { demarcating land in suitable } \\
\text { places and facilitate } \\
\text { infrastructures and services } \\
\text { for mariculture development. }\end{array}$ \\
\hline
\end{tabular}

IX. THE Blue ECONOMY (BE)

The BE includes key industries and resources such as fisheries and aquaculture, transport and logistics, water resources, shipping, marine renewable energy, minerals, genetic resources, pharmaceutical, biotechnology and general sea-based products. The BE strategy of Namibia outlines targets to be achieved by 2022 (NDP5, 2017). This includes the implementation of spatial planning for governance and management of marine resources. The BE strategies will create necessary enabling conditions for entry by European investors into the sector because it strives towards improved and innovative fishing practices such as value addition, research and innovation. Investors need to participate in stakeholder consultation and when necessary, give advices such as on spatial planning.

Every year the Ministry of Fisheries and Marine Resources convenes an annual stakeholder meeting. The representatives of fishing associations are the right stakeholders to contact for details.

\section{INVESTMENT, REGULATORY AND POLITICAL ENVIRONMENT}

Namibia is a multiparty democracy and an upper middle-income country with a population of 2.5 million (https://www.worldbank.org/en/country/namibia/overview). The country is perceived as politically stable, business-friendly with a robust macroeconomy that is regionally competitive (Global Competitiveness Report, 2018). Political violence is rare and damage to commercial projects or installations is considered unlikely. Recent presidential elections in November 2019 have resulted in the re-election of President Dr Hage Geingob and the 
SWAPO party for the next five years; abide no longer with a twothirds majority.

The government has stated its intention in the Harambee Prospective Plan (HPP), Namibia's fifth Development Plan (NDP5) and VISION 2030 to "Encourage local value-adding through domestic processing of fish". The existing national strategies effectively support this. This means Government supports fish processors in a way that facilitates them to undertake market research and product development, which in turn stimulates job creation and encourages lasting investment and improvements in infrastructure to stimulate fisheries valueaddition.

\section{A. Tax and Non-Tax Based Investment Incentives}

According to Deloitte report (2017), the Namibian president has signed the new Namibia Investment Promotion Act No.9 of 2017, which is intended to support small local businesses, however it can also deter foreign investment as it excludes foreign companies. Furthermore, Namibia's Ministry of Industrialisation lists several incentives that apply equally to domestic and foreign investors in Namibia that include the following:

\section{B. B. Tax incentives for registered manufacturing enterprises}

For companies engaged in manufacturing, but not eligible to fish and meat processing companies. By decree of parliament of 20 February 2020, these benefits will seize to exist in their totality as from 1st April 2020.

\section{Export Processing Zones (EPZs)}

EPZ enterprises qualify for total relief from income tax, VAT, customs and excise duties, stamp duty and transfer duty (however not employee related tax). Requirements for EPZ status include conducting a manufacturing activity and exporting at least $70 \%$ of the manufactured goods outside of SACU. By decree of parliament of 20 February 2020, these benefits will seize to exist in their totality as from 1st April 2020.

\section{Capital allowances}

The fishing industry does not benefit from this except the seafoodcanning sector that can obtain Manufacturing Status registration. Capital allowances is meant for buildings used for the purposes of trade, $(20 \%$ of the cost of erection may be written off in the first year of use, and $4 \%$ may be written off annually over a 20 -year period) whose $4 \%$ allowance is increased to $8 \%$ for certain manufacturing buildings, and the write-off period is reduced to 10 years. A general three-year write-off period applies for fixed assets other than buildings (e.g., plant, machinery, equipment and ships), with an accelerated write-off period for certain expenditure relating to mining operations and farming operations.

\section{E. Exports}

Namibia exports most of its hake and monkfish to the EU through Spain. Most hake are exported as headed and gutted, or as fillets or fillet portions. Monkfish it is mostly exported as tails, as the head is cut off as the main eating flesh is in the tail. About 123,000t were exported in the third quarter of 2018 , with close to $18,000 \mathrm{t}$ going to Spain (Maria, 2019). The Total Allowable Catch for Rock Lobster was set at 200t in 2018 (Chamwe, 2018).

\section{EUROPEAN POTENTIAL COMPANIES}

There are potential European companies that might be interested in getting active in the Namibian fisheries sector.

i. Federation of European Aquaculture Producers (FEAP) (http://feap.info/)

EPA is a Federation of National aquaculture association in Europe that represent professional fish farming. It is active in promoting and participating in research and support/coordination projects that contribute to innovation and development of the European fish farming sector.

ii. Parlevliet \& Van der Plas (https://www.pp-group.nl/) Parlevliet \& Van der Plas - or just PP - is a Dutch enterprise, which comprises three major divisions: pelagic fishing, demersal fishing and processing plants. PP is a major global player in the fishing and processing industry, which also works closely together with scientists, environmental organisations, governments and fishery management bodies, to ensure sustainable fisheries and effective fish stock management. Its headquarters are in Valkenburg, Netherlands and a technological fishing plant in Rügen, Germany.

iii. Europacifico company (http://www.europacifico.net/)

EUROPACIFICO is a producer and exporter of frozen fish located in Vigo, Spain, where it has its headquarters and its cold store. It has quality frozen products, among others: Australis Hake hgt \& fillets, Kingklip hgt \& fillets, whole round Cuttlefish, Savorin, Tiger Sole, Brama Australis fillets, Monkfish tails from South Africa and sea-frozen Monkfish tails. According to the company's website, no monkfish tails from Namibia.

iv. Cornelis Vrolijk (http://www.cornelisvrolijk.eu/) Cornelis Vrolijk is an international business in the Netherlands with the fifth generation at the helm. The company is specialised in catching, breeding, processing and trading fish and shrimp. It does fish and trade in pelagic fish species (herring and mackerel), demersal fishing (sole and plaice) and the catching and breeding of (tropical) shrimps.

v. Labeyrie Fine Fioods (France) (http://www.labeyriefine-foods.com/en/home/)

A French company specialized in value chain of different fish species such as cod, sea bass, salmon, cinnabar goatfish, mackerel, sardines, sea bream, salmon, herring cod fish etc.
vi.
Bolton
Alimentari
(Italian
(http://www.boltongroup.net/en-ww/homepage)
company)

Bolton Alimentari is the leading producer of canned fish in Italy with the brands Rio Mare and Palmera. It is rated number 1 in Europe in the canned tuna market and it owns fishing vessels.
vii.
Austevoll Seafood
(https://www.auss.no/)
ASA
(Norway)

Austevoll is specialized in value chain, fishing, farming and distribution of salmon, white fish, pelagic and different food industries as well as seafood supply chain.

\section{OPPORTUNITIES FOR EUROPEAN COMPANIES}

The Namibian fishing sector requires substantial investments in order to create more jobs, marine research and to transform the country's economy. Opportunities for fish and seafood exports to Europe are mainly in Southern Europe, North Western Europe and the Nordic countries. European companies can therefore be significant drivers of investment and innovation in the Namibianfishing sector through value addition by improving processing as 
well as cross-border marketing of fisheries products, into the EU markets and beyond.

UNAM is teaching fisheries courses but not on processing, seafood retailers, fishmongers, bivalve purification, technical courses such as navigation, marine engineers to operate fishing vessels etc. Namibia needs apprenticeship institutions to build qualifications that focuses on fish, seafood, shellfish retail, processing and manufacturing.

i. Opportunities for value-added fishery production systems

Namibia's market for hake, monk and horse mackerel is growing. The MFMR under NDP5 and HPP has committed to $70 \%$ value addition in horse mackerel, and a $40 \%$ increase in fishing related activities in Walvis Bay port by 2022, (NDP5, 2017). Therefore, there is an opportunity in producing a variety of products for high profit such as mince and mince-based products like fish sausage, burger, fingers, cutlet, nugget and ball.

ii. On-shore processing

There is a space for onshore processing of sea frozen Large pelagic (tunas, swordfish, and sharks) landed in frozen form and exported as whole round or de-headed, winged and tailed (DWT), with no value addition. Namibia's fisheries sector's total landings range between 510,000t and 550,000t annually, which is valued at about N\$10 billion (about 625 million EUR) (Leandrea Louw, 2018). However, the industry is facing some challenges. Processing is done on land, which is more expensive than processing on board. There is opportunity to establish on board processing factories to further process these landings into different products.

iii. Mariculture

The potential for mariculture in Namibia is high and can certainly be tapped using sustainable approaches. Mariculture concentrates on molluscan shellfish best suited to the productive upwelling system of the Benguela. Oysters are sought after because of their exceptional quality and Namibia is looking into potential to access the European markets. The bivalve mollusc industry is the most represented in the mariculture sector in Namibia. However, there are no establishments approved for EU export of live bivalve molluscs in Namibia as standards (establishment structural, hygiene, Hazard Analysis Critical Control Points (HACCP) and packaging (of oysters) are not in line with the EU equivalent requirements with regard to cadmium and lead. Additionally, the maximum levels of dioxins and Polychlorinated Biphenyls (PCBs) in live bivalve molluscs are not provided in Namibian standards. Commercial "marine aquaculture" (mariculture) is based on the following:

$\begin{array}{ll}\circ & \text { Seaweed (Gracilaria verrucosa) } \\ \circ & \text { Abalone - (Haliotis midae) } \\ \circ & \text { Mussels (Mytilus galloprovincialis) } \\ \circ & \text { Oyster - (Crassostrea gigas) and (Ostrea edulis) }\end{array}$

This publication is licensed under Creative Commons Attribution CC BY

http://dx.doi.org/10.29322/IJSRP.11.10.2021.p11802

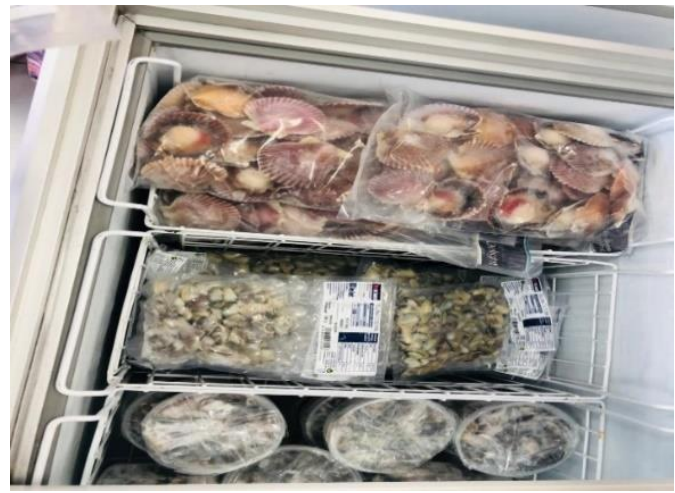

Picture2: Oysters and shellfish (Source:Tangeni Haimbala)

iv. Fishing vessels

Investment and funding are required in the area of vessel replacement where many vessels used for fishing are relatively old; nearing the end of their commercial life and require high maintenance. There might also be export opportunities for German equipment manufacturers. As fishing in Namibia is a capitalintensive industry, companies are looking to acquire equipment/vessels that will reduce overall operating costs.

German technology and know-how are for both repair and ship building or supply. This includes companies such as: USM-Nord Unterweser Schiff- und Maschinenbau GmbH.

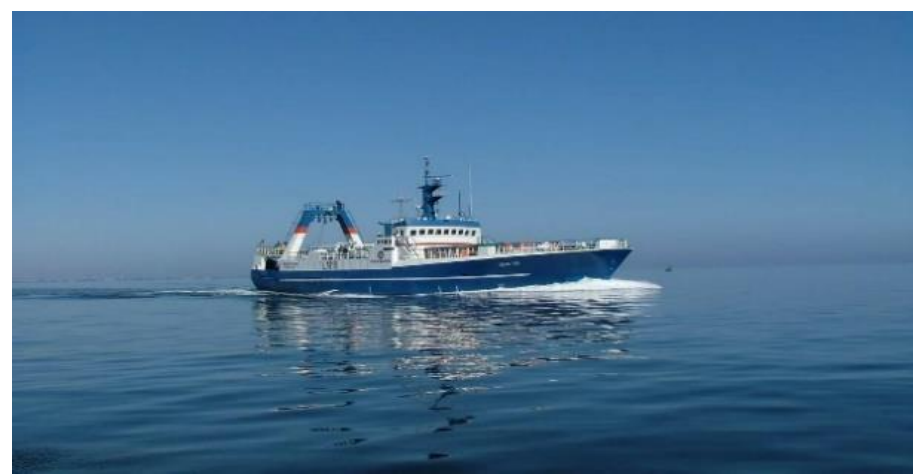

Picture 3: Fishing vessel for Seawork

v. Joint ventures

The government of Namibia emphasizes the need for investors to collaborate with Namibian-owned companies or have many local employees in order to operate in the country. There is an opportunity for German/European companies to establish joint ventures with Namibian companies. The companies include: Pomona Fishing (Pty) Ltd, Estai (Blue Sea Fishing Company), Noordburg Kalapuse (Namcrab Fishing (Pty) Ltd, Omualu Fish Processors (Pty) Ltd, Amansio (Belinda Fishing Namibia CC), Pemba Bay (Seacope Freezer Fishing (Pty) Ltd), Kaveke Katamila (Oshimada Fishing (Pty) Ltd), Atlantic Commercial Cold Store, Tangeni Bay (Namibia Seafood Industries Sashimi (Pty) Ltd.)

Namibian government foster foreign investment in the sector mainly through Namibian companies forming joint ventures with overseas expert operators who then base themselves in Namibia. This allows local fish products to enter the international market under European firms' brand names. This arrangement has shown success if the local firms do not seek to operate directly in the EU market, as this would go against the ministry's mandate. 
The EU joint venture partners with Namibian companies are Spanish (Pescanova, Mascato, Iberconsa, Pereira Fishing, Pesca Puerta (Tunacor), Marfrio and Copemar), except for AllFish which is German, and is associated with Seawork of Walvis Bay. Seawork exports approximately 10,000t of produce into the EU. Most of this volume is Cape Hake, alongside small quantities of Monkfish and Kingklip (https://www.undercurrentnews.com/). Merlus Seafood Processors of Walvis Bay is linked to Mascato of Spain. Tunacor Fisheries of Walvis Bay, while not through direct ownership but more through marketing is linked to Pescapuerta. Cadilu/Embindwa of Walvis Bay is linked to Iberconsa. Grupo Pereira of Walvis Bay is linked to Grupo Pereira of Spain. Novanam of Luderitz is linked to Pescanova. There are no associations linked and details about these companies are not provided.

Other forms of investment opportunities include freezers, packaging, containers, equipment, purchases of fish shops, and shares in the vessels and processing plants. Due to the concentration of industrial activities around the port, several subsectors are also of interest to foreign investments such as engines and supply systems for vessels, renewable energy, water desalination systems, industrial ice-making systems and freshwater aquaculture equipment.

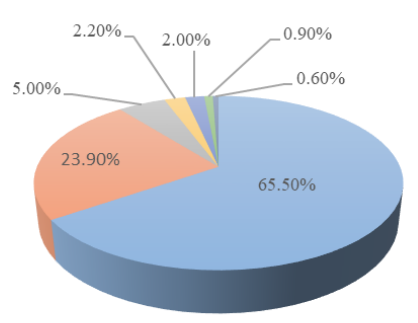

2018

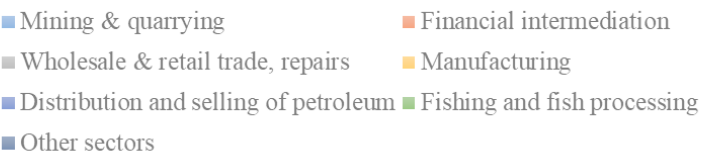

n Other sectors

Figure 3:Direct investment by sector 2018 (Source: Bank of Namibia, Annual Report 2018)

XIII. CHALLENGES IN THE FISHING SECTOR

Several challenges hinder the fishing industry in Namibia and may constitute opportunities for investment in the sector. One of the key challenges, also addressed in the NDP5 is the enhancement of the fisheries major access to lucrative export destinations by ensuring compliance to more stringent Sanitary and Phytosanitary Standards (SPS). This involves strengthening existing certification system on export, including robust control measures on Hazard Analysis Critical Control Point (HACCP), aquaculture and fisheries healthy systems. Currently, Namibia is importing fish such as small pelagic for canning and Patagonia squid for value addition and re-export to various countries. This takes place at Seagull Fish Processors, Tunacor and Corvima companies in Walvis Bay. The Patagonia squid is caught in Argentinian waters off the western Atlantic, bought and imported in raw form to Namibia. Such fish importation practice needs to be stimulated in order to achieve the substantial volumes needed for economic of scale in value addition activities such as canning.
Varying climatic conditions also contribute to high fluctuating granted annual quotas. This has led to equally fluctuating investment, trade and job trends in the sector. Personnel lay-offs is the most common result when annual fishing quotas are lowered. The years 2013 to 2019 were noted as particularly challenging on the sector in this regard (Personal Discussions MFMR 2019).

i. Lack of transparency

The procedures for granting fishing quotas, attaining Export Processing Zone (EPZ) and Registered Manufacturer Status lack harmony and transparency. In 2019, the industry experienced a widely exposed scandal, commonly referred to as the 'Fishrot Scandal', which included bribing of Namibian high-ranking politicians in exchange of fishing quotas. This has put a shadow over the fishing industry and calls for regulatory reforms towards more transparency. As a result of the scandal, more fishermen than during economic trying times were left on the street without jobs, adding a burden to the already high unemployment rate in the country. Nevertheless, with the appointment of the new minister, the sector is reviewing all affairs and administration to correct the wrongdoings. It is expected that application for new fishing rights will soon be announced.

ii. Legislation

Existing legislation is interpreted differently in different ministries, leading to confusion on how the private sector is to comply with regulatory provisions. As a result, the lack of coordination between government departments is counterproductive. This has been observed when carrying out this research as government officials are hesitant to collaborate and avail data. Some ministries such as the MFMR and MITSMED are working hard to promote value addition, however, the Ministry of Finance is not providing the necessary incentives for the fish processing industry to achieve this. Government policy makers need to align their policies with the private sector in a synergistic manner to ensure that the policy framework creates an enabling environment for the private sector. A conducive environment will attract more foreign buyers and investors, hence increase the overall marketability of the sector. It is important to ensure that all stakeholders agree on the interpretations of existing legislation designed to foster greater value-addition and investments.

iii. Lack of skilled labour

There is a shortage of specialized skilled labour in Namibia. Labour productivity and the shortage of skilled labour are the biggest obstacles to business growth. Low level of technical skills, an inadequately educated workforce, poor management and insufficient skills to expand the resource supply remain a challenge to the fishing sector in Namibia. Shortage of some value chain actors to expand the resource supply and deficiency of investment are some of the capacity constraints in the Namibian fishing industry. Unskilled engineers and navigators on board the fishing vessels also affect the fishing sector. There is a need for capacity building in order to increase the productivity and meet international standards. As such investment by EU companies will increase the capacity to absorb business skills, expand the number of skilled labour and improve natural resources management.

iv. Poor branding and lack of financial support

The current retail value added products (VAP) producers are predominantly foreign players, and products are not promoted 
abroad with any recognised Namibian branding. In addition, Namibian owned seafood companies do not have financial capability to introduce own brands into retail sector overseas as this costs millions of Euros, neither to ensure that their indigenous knowledge is recognised in the market. It would already help if foreign owned companies are legally compelled to clearly state the origin of the resource. Therefore, opportunity to develop brands for the Namibian fishing industry facilitates a break into high-end international fishing markets.

\section{v. Illegal, unreported and unregulated Fishing}

The threat posed by illegal, unreported and unregulated (IUU) fishing activities is widely recognised off the Namibian waters in the northern maritime border with Angola. Monitoring, evaluating and reporting is further hampered by lack of financial resourcing. Other challenges include lack of access and credible data due to insufficient research in the sector, lack of Foreign Direct Investment (FDI) to promote local investment and integrate projects into domestic value chains. A lack of coordination and integration between stakeholders due to weak regulatory and legal framework, which ensures appropriate planning, management, and governance.

\section{TRADE FACILITATION}

The Directorate of International Trade of the MITSMED is responsible for coordinating the country's trade policies, participation in international trade and managing import/export procedures. Imports of fisheries/ seafood into the EU are subject to official certification by NSI. As a first step, companies wishing to export fisheries/ seafood products to the EU should contact the NSI for certification and compliance standards.

In 2016, Namibia together with other six SADC countries signed the Economic Partnership Agreement (EPA) with the European Union, called EU-SADC EPA, which is now in force. This agreement provides duty and quota-free market access to EU markets as well as derogations and cumulations on fisheries. In other words, no exports from Namibia to the EU will attract duties although there is a restriction on the quantity of such exports to the EU for processed fish resources. Unprocessed marine resources neither attract quota restrictions nor import duties into the EU. However, under the same agreement, Namibia imposes export levies and duties on any unprocessed natural resources (Government Gazette of 18 December 2019; administered under the Customs and Excise Act, Act 20 of 1998).

The SADC-EU EPA also provides for projects to develop SPS capacity of the private sector and the ministry, as the competent authority. Namibia is also a member of the following trade agreements: World Trade Organization (WTO), Common Monetary Union (CMU), the World Bank's Multilateral Investment Guarantee Agency (MIGA) and a beneficially of African Growth Opportunity Act (AGOA). Namibian products also qualify for preferential market access to 34 countries under the Generalized System of Preferences (GSP), which provides tariff reduction on various products.

\section{CONCLUSIONS}

After numerous interviews with different industry executives, government officials and a careful examination of the industry per se, it is important to point out that economic activities in fisheries, remain domestically oriented, informal and limited due to limited (foreign) investment, technology and skills' transfer which resulted in limited economies of scale and hence value addition. The Namibian government through its fisheries and marine resources ministry should build on a positive trend to facilitate entry for European investors in the sector by strengthening trade policies, allow for know-how transfer by relaxing immigration conditions for foreign skills import, and consider relaxing the most stringent investment terms and conditions to their own companies and foreign companies in general. There are opportunities for investment to expand the sector and the market is open for European investors despite constraints such as corruption. The sector is optimistic that reforms will make the sector more transparent, especially when it comes to the allocation of fishing rights and annual quotas. There is considerable opportunity in the maricultutre sub-sector. Registering of manufacturing status and export processing zone may need be adjusted to favour the fisheries sector by incorporating mariculture and seafood processing. This can pave ways for European investors to focus more on mariculture which has a great potential to access the European market.

Therefore, it is crucial for European investors to have a good understanding of the Namibian regulatory framework and the social political structure. It is further advisable to engage and form strong partnerships with local companies. European companies are also recommended to conduct an in-depth market assessment and engage with (key market players), the private sector stakeholders in the industry.

\section{REFERENCES}

[1] Abed Shiyukifeni, Manager, Inspection Center, Namibia Standard Institution, Walvis Bay, Namibia. Personal Communication.

[2] ADAM HAR, A. (2019). Towards a blue economy. The Namibian. Available at:

https://www.namibian.com.na/public/uploads/documents/5c890066c07bd/F ishing\%202019.pdf. [15 October 2020].

[3] Bank of Namibia. 2018 Annual Report. Republic of Namibia. Available at https://www.bon.com.na/Publications/Annual-Reports.aspx. Accessed [11 October 2020].

[4] Chiripanhura, B. \& Teweldemedhin, M. (2016a). An analysis of the fishing industry in Namibia: The structure, performance, challenges, and prospects for growth and diversification.

[5] Chumwa Caira (2018). New fishing rights to be awarded only next year. Windhoek Observer. Available at: https://www.observer.com.na/. Accessed [12 October 2020].

[6] Compliance of Imports of Fishery and Aquaculture Products with EU Legislation (2013). Available at http://www.europarl.europa.eu/studies Accessed [19 October 2020].

[7] Deloitte, 2017b. Namibian Budget 2017/2018 Commentary. Available [Online]: https://www2.deloitte.com/na/en/pages/tax/articles/namibiabudget-2017-2018.html. Accessed [18 October 2020].

[8] EU Commission (2012). Final Report of an Audit Carried Out in Namibia. Available at: https://ec.europa.eu/food/audits_analysis_en. Accessed [18 October 2020].

[9] EPA (2016), Economic Partnership Agreement between the European Union and the Southern African Development Community (SADC) EPA Group. Available at: https://ec.europa.eu/info/index_en. Accessed [09 October 2020].

[10] FAO, 2018. The State of World Fisheries and Aquaculture 2018 - Meeting the sustainable development goals. Rome. License: CC BY-NC-SA 3.0 IGO.

[11] Growth Strategy for Namibia's Seafood Industry and Associated Value Chains. (MITSMED) 
[12] Louw, L. Silver jubilee celebrations for Walvis Bay: Creating a culture of unity within diversity should be the order of the day. Erongo Newspaper, August 11, 2019. Available at: http://www.erongo.com.na/. Accessed [08 October 2020].

[13] Louw, L. (2018) Promote fish consumption, says minister. Walvis Bay: Erong Newspaper.

Available

at: https://www.erongo.com.na/news/promote-fish-consumption-saysminister2018-03-23/?Array. [19 October 2020].

[14] Ministry of Fisheries and Marine Resources, 2013. Annual Report. Republic of Namibia.

[15] Ministry of Fisheries and Marine Resources, 2016. Annual Report. Republic of Namibia.

[16] Namibia First Annual State of Logistics Report, 2018. Walvis Bay Corridor Group Publications. Available at: http://www.wbcg.com.na/ Accessed [14 October 2020].

[17] Ministry of Fisheries and Marine Resources, 2019. Annual Ministerial Address to the Fish Industry. Available at http://www.mfmr.gov.na/. Accessed [14 October 2020].

[18] Ministry of Industrialization, Trade and SME Development, 2017. Available [Online]: http://www.mti.gov.na/. Accessed [13 October 2020].

[19] Namibia Fifth National Development Plan (NDP5), 2017. Working together towards prosperity 2017/18 - 2021/22.

[20] Namibia First Annual State of Logistics Report (2018). Walvis Bay Corridor Group Publications. Available at http://www.wbcg.com.na/. Accessed [08 April 2020].

[21] Namibia Ministry of Fisheries and Marine Resources (MFMR) Marine Resource Policy (2004). Available at http://www.mfmr.gov.na. Accessed [09 October 2020].

[22] Namibia Ministry of Fisheries and Marine Resources (MFMR). Marine Resources Act no.27of 2000. /http://www.mfmr.gov.na; 2000 [09 October 2020].

[23] Namibia Statistics Agency. 2018. Annual National Accounts 2017. NSA, Windhoek, available at https://nsa.org.na/page/publications/. Accessed [19 April 2020].

[24] Namibia's Industrial Policy Implementation and Strategic Framework 2014 $-2017$.

[25] Namibian Ports Authority, 2018. Annual Report. Available at https://www.namport.com.na/. Accessed [09 June 2020].
[26] National Development Plan of Namibia (2017). Available at: https://www.npc.gov.na/?page_id=948. Accessed [18 June 2020].

[27] NSA, 2017c. Annual Trade Statistics Bulletin 2016. Available [Online]: https://cms.my.na/assets/documents/Annual_Trade_Statistics_Bulletin_201 6.pdf. [19 October 2020].

[28] Walters, R. January 2020. Secretary, Namibia Hake Association, Walvis Bay, Namibia. Personal communication.

[29] Russell, D. (2007). Assessment of Opportunities for Increased Value Addition and Improved Marketing of Namibian Marine Fish Products.

[30] Russell, D. 4 August 2005. Issues and Strategies for Value Addition and Trade of African Fish and Fish Products.

[31] Status of Namibian Economy (2018). National Planning Commission of Namibia. Available at https://www.npc.gov.na/?page_id=20. Accessed [19 June 2020].

[32] T. Haimbala (2019). Sustainable growth through value chain development in the blue economy: a case study of the port of Walvis Bay. World Maritime University, Malmo, Sweden.

[33] The Global Competitiveness Report (2018). World Economic Forum. Available at http://www.weforum.org/gcr. Accessed [19 June 2020].

[34] The SADC-EU Economic Partnership Agreement (2016). EPA brochure agreement. UNCTAD, World Investment Report 2019; http://unctad.org/wir or http://unctad.org/fdistatistics. Accessed [19 June 2020].

[35] Undercurrentnews. Available at: https://www.undercurrentnews.com/. Accessed [19 June 2020].

[36] US Department of State, 2016. Namibia 2016 Investment Climate Statement. Available at https://www.state.gov/e/eb/rls/othr/ics/2016/af/254227.htm. Accessed [09 August 2020].

[37] XE Currency Converter: Available at: https://www.xe.com/currencyconverter/. Accessed [24 October 2020]..

\section{AUTHORS}

First Author - Tangeni Haimbala, MSc Ocean Sustainability, Governance and Management,

University of Natural Sciences and Life Sciences

haimbalatangeni@yahoo.com. 